\title{
Factors Affecting Audit Delay with Reputation of Public Accountant Office as a Moderating Variable in Manufacturing Companies Listed on the IDX in 2009-2020
}

\author{
Gabriel Abdillah $^{1}$, Iskandar Muda ${ }^{1}$, Erwin Abubakar ${ }^{1}$ \\ ${ }^{1}$ Department of Accounting, Faculty of Economics and Business at Universitas Sumatera Utara, Indonesia.
}

Corresponding Author: Gabriel Abdillah

DOI: https://doi.org/10.52403/ijrr.20220249

\begin{abstract}
This study aims to determine the effect of audit tenure, audit opinion, firm size, and profitability on audit delay in manufacturing companies listed on the Indonesia Stock Exchange. In addition, this study also aims to determine whether the reputation of a public accounting firm can moderate the effect of audit tenure, audit opinion, firm size, and profitability on audit delay in Manufacturing Companies Listed on the Indonesia Stock Exchange.

This type of research is causal associative research. The location of this research was carried out on Manufacturing Companies listed on the Indonesia Stock Exchange 2009-2020. The number of samples in this study was 33 companies, so the number of observations amounted to 396 data. This research uses the regression analysis method and interaction test with the help of Eviews software.

This study indicates that audit opinion, firm size, and profitability have a negative and significant effect on audit delay in Manufacturing Sector Companies Listed on the Indonesia Stock Exchange. Meanwhile, audit tenure does not have a significant effect on audit delay. Other results show that public accounting firm reputation can moderate the effect of audit tenure on audit delay. Meanwhile, on the effect of the audit opinion, firm size and profitability are not.
\end{abstract}

Keywords: audit tenure, audit opinion, firm size, profitability, public accounting firm reputation, audit delay.

\section{INTRODUCTION}

The demand to present financial reports promptly faces several obstacles. One of them is that a public accountant must audit the financial statements. Constraints due to this audit process are usually called audit delays or, in other studies, stated by audit report lag. Puspitasari and Latini (2014) define "audit delay as the time difference between the end of the fiscal year and the date of issuance of the audit report."

The longer the audit delay, the longer the auditor will complete the audit work. Audit delay is the most crucial determinant of timeliness in earnings announcements and will ultimately determine the market reaction to earnings announcements. The time difference between the date of the financial statements and the date of the audit opinion in the financial statements indicates the length of time to complete the audit work (Habib et al., 2018). So that delays in the submission or publication of financial statements. Naimi et al. (2010) explained that the length of the audit delay that occurs would affect investors' decision-making because delays in informing investors can affect investor confidence in the capital market.

Delays in submitting financial statements can be a problem for companies and lead to negative responses from capital market participants, especially investors. 
Therefore, audited financial statements have significant benefits in measuring and assessing a company's performance for decision-makers. The audited financial statements contain a report on the company's financial position, the company's results of operations, and changes in the company's financial position, which are intended for internal and external parties (Dewangga, 2015).

The information contained in the financial statements will be valuable if presented accurately and on time; that is, it is available when the users of financial statements need it. Timeliness of financial statement presentation (timeliness) and length of audit completion (audit delay) as a measure of the success of a company are the main prerequisites for improving company quality (Azizkhani et al., 2018). The timely presentation of audited financial statements to the public signals helpful information for investors and other users of financial statements for decision making (Puspitasari and Sari, 2012).

On the other hand, the longer the delay in presenting a company's financial statements to the public, the more the possibility of developing issues and insider information about the company. The longer the time for publication of the annual financial statements since the end of a company's financial year, the more likely the information will leak to confident investors or even cause problems for the company on the stock exchange.

Since July 29, 2016, Financial Services Authority issued Regulation Number 29/POJK.04/2016. It states that issuers or public companies whose registration statements have become effective must submit annual financial reports to the Financial Services Authority no later than 4 (four) months after the end of the financial year.

If it is found that there are parties who violate the provisions of Financial Services Authority regulations, the Financial Services Authority has the authority to impose administrative sanctions in the form of written warnings; fines, namely the obligation to pay a certain amount of money, restrictions on business activities, freezing of business activities, revocation of business licenses, cancellation of approvals, and cancellation of registration. However, despite the stipulation of rules regarding the annual reports of issuers or public companies and their sanctions, there is still a phenomenon in which some companies are late in reporting financial statements every year. It was recorded that in 2015, 2016, and 2017 many companies were reported to be late in reporting their financial statements and were subject to sanctions.

In 2015, the Indonesia Stock Exchange gave warnings to companies that had not submitted financial reports on December 31, 2014. The number of issuers that received warnings was 52 companies. Of the total 52 companies, 12 of them are manufacturing companies. There is even one company that, until 2017, was recorded as always late in submitting its annual financial reports, namely Eterindo Wahanatama Tbk (ETWA). The following is a table of the phenomenon of delays in submitting financial reports to manufacturing companies listed on the IDX:

Table 1. Manufacturing Companies That Are Late In Submitting Financial Statements

\begin{tabular}{|l|l|l|l|l|}
\hline \multirow{2}{*}{ No } & \multicolumn{4}{|l|}{ Delay in delivering financial statements } \\
\cline { 2 - 5 } & $\mathbf{2 0 1 5}$ & $\mathbf{2 0 1 6}$ & $\mathbf{2 0 1 7}$ & $\mathbf{2 0 1 8}$ \\
\hline 1 & ADES & AGII & ETWA & SCPI \\
\hline 2 & AGII & ALTO & SCPI & \\
\hline 3 & AISA & ARGO & & \\
\hline 4 & AKPI & BRNA & & \\
\hline 5 & ALTO & ETWA & & \\
\hline 6 & BRNA & PBRX & & \\
\hline 7 & ETWA & SKBM & & \\
\hline 8 & ISSP & & & \\
\hline 9 & MYTX & & & \\
\hline 10 & SCPI & & & \\
\hline 11 & SIPD & & & \\
\hline 12 & VOKS & & \\
\hline \multicolumn{5}{|c|}{ Source: Indonesia Stock Exchange (IDX) } \\
\hline
\end{tabular}

The phenomenon regarding the delay of manufacturing companies in submitting financial reports above indicates that at the end of each year during the closing period, public companies are still constrained in submitting annual financial 
reports and causing audit delays. However, on the other hand, it turns out that the number of manufacturing companies that are late in submitting their audited financial statements continues to decrease in number from year to year. So this must be maintained so that there will be no more companies that are late in submitting their financial reports in the future.

The delay in the submission of financial statements indicates the importance of knowing what factors can affect audit delay in companies. Factors that are thought to affect audit delay include audit tenure (Dao and Pham, 2014; Habib and Bhuiyan, 2011; Mariani and Latrini, 2016; Michael and Rohman, 2017; and Wulandari and Wiratmaja, 2017), audit opinion (Apriliane, 2015; and Amani, 2016), firm size (Khalatbari, et al., 2013; Febrianty, 2011; and Indriyani and Supriyati, 2012; Kartika, 2009; and Apriyana and Rahmawati, 2017) and profitability (Soedarsa and Nurdiawansyah, 2017; Miradhi and Juliarsa, 2016; Murti, 2016; and Apriyana and Rahmawati, 2017).

Audit tenure is the period of work engagement between the auditor and his client in examining the report (Singh et al., 2019). The long tenure of a Public Accountant Office can increase the auditor's understanding of his client's business (Giri, 2010). Indonesia is one of the countries that stipulates a time limit for the engagement of the Public Accountant Office. The limitation is intended to keep the Public Accountant Office from being too familiar with the client because excessive familiarity is considered to reduce the independence of the Public Accounting Office. The time limit for the engagement of the Public Accountant Office in Indonesia is regulated in the Regulation of the Minister Finance of Republic Indonesia Number 17/PMK.01/2008.

To understand the client and the industry being audited, auditors need more time in the early years of the audit engagement, which causes longer audit delays. So it can be concluded that the long audit delay can be caused by short audit tenure (Obradovic et al., 2018).

The research results conducted by Dao and Pham (2014) show that audit tenure has a negative and significant effect on audit delay. Habib and Bhuiyan (2011); Mariani and Latrini (2016); Michael and Rohman (2017); and Wulandari and Wiratmaja (2017) state that audit tenure can significantly affect audit delay.

Furthermore, factors that are thought to affect audit delay include audit opinion. The auditor's opinion is a statement resulting from a judgment. An audit opinion is a report given by a registered public accountant due to his assessment of the fairness of the financial statements presented by the company (Muhammad, 2020). The auditor's report is a means for the auditor to express his opinion, or if circumstances require, to disclaim an opinion. Suppose the auditor expresses an opinion or disclaims an opinion. In that case, he must state whether the audit has been carried out following the auditing standards set by the Indonesian Institute of Certified Public Accountants.

In doing so, the auditor must collect evidence of the fairness of the information contained in the company by examining the accounting records that support the report. The auditor's statement of opinion must be based on the audit carried out based on the auditing and its findings (Astuti and Darsono, 2012) so that the auditor's opinion on the audited financial statements becomes a benchmark and is used as the basis for users in making decisions (Akingunola et al., 2018). The audit opinion consists of an unqualified opinion, an unqualified opinion with explanatory language, a qualified opinion, an adverse opinion, and a disclaimer.

Apriliane's research (2015) results show that audit opinion significantly affects audit delay. Companies that receive qualified opinions will experience an increasingly longer audit delay. The audit granting process will involve negotiations with clients and consultation with more 
senior audit partners. In contrast to companies that receive an unqualified opinion, audit delay tends to be shorter because the company will not delay the publication of financial statements containing good news. It is also supported by the results of previous research conducted by Amani (2016), who stated that audit opinion significantly influenced audit delay.

The next factor that is thought to affect audit delay is firm size. Firm size is a scale where the company's size can be classified according to various ways, including total assets, stock market value, number of employees, and others. According to Brigham and Houston (2014), firm size is the size of a company indicated or assessed by total assets, total sales, total profits, tax expenses, and others. The size of the company is only divided into three categories, namely large companies (large firms), medium companies (medium size), and small companies (small firms). Pourali et al. (2013) stated that the management of large companies would have an incentive to reduce audit delays and delays in submitting financial statements, which is because these companies are monitored closely by investors, capital supervisors, and the government.

In this study, the company's size is proxied by the total assets owned by the company. Total assets were chosen because they describe their size more than revenue. Total assets show the wealth managed by the company since it was first established, while income is only the result obtained by the company in one period.

The results of research Ashton et al. (1987); Khalatbari et al., (2013); Febrianty (2011); and Indriyani and Supriyati (2012); mentions that large companies report faster than small companies. Thus, it can be said that firm size is a factor that affects audit delay. Likewise, Kartika's (2009) research states that firm size significantly affects audit delay.

The next factor that is thought to affect audit delay is profitability. Pham et al.
(2014) explained that profitability is used to analyze management performance. Investors in the capital market are very concerned about the company's ability to generate and increase profits; this is an attraction for investors in buying and selling shares; therefore, management must meet the targets that have been set.

The company's ability to earn a profit depends on the efficiency and effectiveness of its operations and the available resources. Companies with a higher level of profitability need time to audit financial statements more quickly due to the need to deliver good news as soon as possible to the public (Dong et al., 2018). They also give reasons that auditors who face companies that experience losses have a response that tends to be more careful in carrying out the auditing process (Estrini and Laksito (2013). If the company produces a higher level of profitability, the audit delay will be shorter than companies with higher levels of profitability- lower profitability (Yuliusman et al., 2020).

The results of previous research conducted by Soedarsa and Nurdiawansyah (2017), Miradhi and Juliarsa (2016), Murti (2016), and Apriyana and Rahmawati (2017) show that profitability is proven to have a significant effect on audit delay.

In this study, the reputation of a public accounting firm is used as a moderating variable for novelty. Public Accounting Office is a form of public accountant organization that is licensed following the laws and regulations, engaged in providing professional services in public accounting. The classification of Public Accounting Offices carried out by the Indonesian Accounting Association operating in the territory of Indonesia is divided into 2 , namely the big four Public Accounting Firms and non-big four Public Accounting Offices.

The categories of Public Accounting Offices affiliated with the big four in Indonesia are:

1. Public Accountant Office Price Waterhouse Coopers collaborates with 
Gabriel Abdillah et.al. Factors affecting audit delay with reputation of public accountant office as a moderating variable in manufacturing companies listed on the IDX in 2009-2020.

the Public

OfficeTanudiredja, Partners.

2. Public Accountant Office KPMG (Klynveld Peat Marwick Goerdeler) collaborates with the Public Accounting Offices Siddharta and Widjaja.

3. Public Accountant Office Ernst \& Young, in collaboration with Purwantono, Suherman, and Surja Public Accounting Offices

4. Public Accountant Office Deloitte Touche Tohmatsu, in collaboration with the Public Accountant Office Osman Bing Satrio.

The reputation of the Public Accountant Office is shown by the high quality resulting from its services, which will affect the audit completion period. Fast audit times are one way for Public Accounting Offices with high quality to maintain their reputation (Puspitasari and Sari, 2012).

This study uses the reputation of the Public Accountant OfficEbecause it is considered capable of strengthening or weakening the influence of audit tenure, audit opinion, firm size, and profitability on audit delay. Public Accounting Firms with a high reputation usually have more employees, better control systems, and resources to work more effectively and efficiently. Based on the results of previous research conducted by Murti (2016), the reputation of the Public Accountant Office is considered capable of moderating audit delay because a good Public Accounting Office's reputation will work more professionally to overcome problems in the audit process.

Based on the above background, the research entitled "Factors Affecting Audit Delay with the Reputation of Public Accounting Offices as Moderating Variables in Manufacturing Companies listed on the Indonesia Stock Exchange in 2009-2020" becomes interesting to do.

\section{Framework}

Following the description of the background of the problem, literature review, and previous research, a conceptual research framework is prepared as follows:

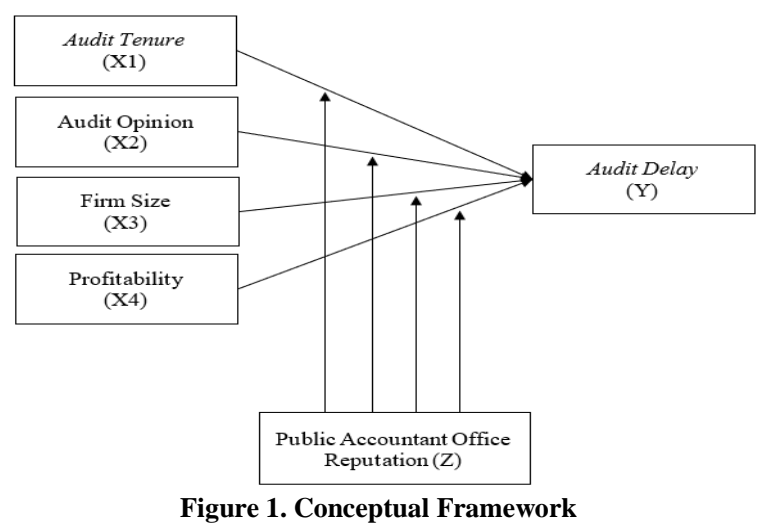

H1: Tenure Audit has a negative effect on Audit Delay in Manufacturing Companies Listed on the IDX in 2009-2020.

$\mathrm{H} 2$ : Audit Opinion has a negative effect on Audit Delay in Manufacturing Companies Listed on the IDX in 2009-2020.

H3: Firm size has a negative effect on Audit Delay in Manufacturing Companies Listed on the IDX in 2009-2020.

H4: Profitability has a negative effect on audit delay in Manufacturing Companies Listed on the IDX in 2009-2020.

H5: The reputation of the Public Accountant Office as a Moderating Variable Strengthens the Effect of Tenure Audit on Audit Delay in Manufacturing Companies Listed on the IDX in 2009-2020.

H6: The reputation of the Public Accountant Office as a Moderating Variable Strengthens the Effect of Audit Opinion on Audit Delay in Manufacturing Companies Listed on the IDX in 2009-2020.

H7: The reputation of the Public Accountant Office as a Moderating Variable Strengthens the Effect of Firm size on Audit Delay in Manufacturing Companies Listed on the IDX in 2009-2020.

H8: The reputation of the Public Accountant Office as a Moderating Variable Strengthens the Effect of Profitability on Audit Delay in Manufacturing Companies Listed on the IDX in 2009-2020. 


\section{RESEARCH METHODS}

This type of research is causal associative research to determine the factors of whether audit tenure, audit opinion, firm size, profitability as independent variables affect audit delay as the dependent variable with the reputation of Public Accounting Firms as moderating variables in Manufacturing Companies listed on the Stock Exchange in 2009-2020.

The causal associative study aims to analyze the relationship between one variable and another to know how one variable affects other variables (Sugiyono, 2011). The data collection method used in this research is the documentation method, namely in the form of reports that have been published in the observation period and then collected, recorded, and reviewed. The data analysis method used in this study is a statistical analysis method using the Eviews application. Data analysis performs by testing standard assumptions and testing hypotheses.

The population of this study consisted of manufacturing companies listed on the Indonesia Stock Exchange as many as 178 companies. The sample selection in this study was conducted using the purposive sampling method. Purposive sampling is a sampling technique using specific considerations (Sugiyono, 2011). Samples were selected using the following criteria:

1. Is a manufacturing company whose shares are listed on the IDX in 20092020.

2. Had an IPO before the year of the study, namely 2009.

3. Published the Annual Report and Audited Financial Reports during the 2009-2020 research period.

4. Manufacturing companies that display the profile of the Public Accountant Office and the Public Accounting Firm.

The researchers obtained manufacturing companies that became the research sample based on these criteria. So the number of observations in this study was
396 units, namely 33 companies x 12 years of research.

\section{RESULT AND DISCUSSION Estimation Model Selection}

Three methods can be used for panel data in this study, namely the Common Effect (CE), Fixed Effect (FE), and Random Effect (RE) regression models. The Chow, Hausman, and Lagrange multiplier tests were carried out to determine the best estimation model in this study.

\section{Chow Test}

A Chow test is carried out to determine the most appropriate fixed-effect or standard effect model used in estimating panel data. This test aims to determine which model is the best between the two, namely fixed effect (FE) or common effect (CE). The determination of the hypothesis used in the Chow test is as follows:

HO: then, the best estimation model used is the common effect rather than the fixed effect.

H1: The best estimation model used is the fixed effect rather than the common effect.

The stipulation is that if the probability is 0.05 , then $\mathrm{H} 0$ is accepted, meaning that the common effect (pool least square) model will be used. However, if the probability value is $<0.05$, then $\mathrm{H} 1$ is accepted, meaning that this research is better off using the fixed effect approach.

Table 1. Chow Test Results
\begin{tabular}{|l|l|l|l|}
\hline Effects Test & Statistic & d.f. & Prob. \\
\hline Cross-section F & 4.555218 & $(32,359)$ & 0.0000 \\
\hline Cross-section Chi-square & 134.946704 & 32 & 0.0000 \\
\hline
\end{tabular}
Source: Results of data processing with Eviews 9

Based on the Chow test, it can be seen that the probability value obtained is 0.000 , which is smaller than $0.05(<0.05)$, so the best model to use is Fixed Effect (FE) rather than Common Effect (CE).

\section{Hausman Test}

After performing the Chow test and determining the fixed effect's best estimate, the next step is to perform the Hausman test 
to retest the better model between fixed effect (FE) or random effect (RE). Following are the test results to choose whether the best estimate is a random effect (RE) or a fixed effect (FE) with the Hausman test. The hypothesis used in the Hausman test is as follows:

$\mathrm{HO}$ : then the best estimation model used is a random effect

H1: The best estimation model used is a fixed effect.

Table 2. Hausman Test Results

\begin{tabular}{|l|l|l|l|}
\hline Test Summary & $\begin{array}{l}\text { Chi-Sq. } \\
\text { Statistic }\end{array}$ & $\begin{array}{l}\text { Chi-Sq. } \\
\text { d.f. }\end{array}$ & Prob. \\
\hline Cross-section random & 4.487455 & 4 & 0.3440 \\
\hline \multicolumn{3}{|c|}{ Source: Results of data processing with Eviews 9}
\end{tabular}

Based on the results of the Hausman test in this study, it can be seen that the PValue of the Random Cross-section is 0.3440 , which is greater than $0.05(0.3440>$ 0.05). Then $\mathrm{H} 0$ is accepted, which means the best method to use is a random effect rather than a fixed effect.

\section{Lagrange Multiplier Test}

To determine whether the best estimation method is a random effect or a common effect, the Lagrange Multiplier Test is carried out. The Lagrange Multiplier test is a statistical test to choose whether the common effect model or the random effect model is more appropriate in panel data regression (Gujarati, 2012). Tests are carried out with the following hypotheses:

1. $\mathrm{HO}=$ Common effect

2. $\mathrm{H} 1=$ Random effect

\begin{tabular}{l} 
Table 3. Lagrange Multiplier Test Results \\
\begin{tabular}{|l|l|l|l|}
\hline & Test Hypothesis \\
\hline & Cross-section & Time & Both \\
\hline Breusch-Pagan & 97.13990 & 3.704299 & 100.8442 \\
\hline & $(0.0000)$ & $(0.0543)$ & $(0.0000)$ \\
\hline
\end{tabular} \\
\hline
\end{tabular}

Based on the Lagrange Multiplier test results in this study, it can be seen that the P-Value of the Breusch-Pagan Crosssection is 0.000 , which is smaller than 0.05 $(0.000<0.05)$. So that $\mathrm{H} 1$ is accepted, which means the best method that must be used in this study is the random effect.
Based on the selection of the estimation method, it is known that the result of selecting the appropriate estimation method for the panel data regression equation in this study is a random effect so that in this study, there is no need to test the classical assumptions on the data used (Gujarati and Porter, 2009).

\section{Research Hypothesis Test Regression Analysis With Panel Data}

The analytical technique used in this study is multiple linear regression analysis with panel data to describe the effect of audit tenure, audit opinion, firm size, and profitability on audit delay. In the selection of the estimation method in the previous section, it can be seen that the best estimation method used in this study is the random effect (RE). So that the results of multiple linear regression analysis of panel data using random effects can be seen in the following table:

Table 4. Panel Data Regression Analysis Results

\begin{tabular}{|l|l|l|l|l|}
\hline Variable & Coefficient & Std. Error & t-Statistic & Prob. \\
\hline C & 117.2596 & 13.65748 & 8.585741 & 0.0000 \\
\hline X1 & 0.358517 & 0.404387 & 0.886568 & 0.3759 \\
\hline X2 & -11.20593 & 2.383918 & -4.700635 & 0.0000 \\
\hline X3 & -1.776340 & 0.899809 & -1.974130 & 0.0491 \\
\hline X4 & -0.503214 & 0.109860 & -4.580503 & 0.0000 \\
\hline \multicolumn{5}{|c|}{ Source: Results of data processing with Eviews 9} \\
\hline
\end{tabular}

Based on Table 4. above, it can be seen that the multiple linear regression equation is:

$$
\begin{array}{r}
Y=117.260+0.358 X_{1}-11.206 X_{2} \\
-1.776 X_{3}-0.503 X_{4}
\end{array}
$$

From these equations, it can be explained as follows:

1. Constant (a) $=117.260$ indicates $a$ constant value, where if the value of all independent variables is equal to zero, then the audit delay variable $(\mathrm{Y})$ is equal to 117.260 .

2. Coefficient of audit tenure $(\mathrm{X} 1)=0.385$, meaning that if audit tenure has increased by 1 unit, it will increase audit delay by 0.358 (35.8\%). The coefficients value is positive, indicating a positive relationship between audit tenure (X1) and audit delay (Y). It means that if the 
audit tenure increases, the audit delay will also increase.

3. The coefficient of audit opinion $(\mathrm{X} 2)=-$ 11,206 , meaning that if the audit opinion increases by 1 unit, it will affect the audit delay of 11.206. The coefficients value is negative, indicating a negative relationship between audit opinion (X2) and audit delay (Y). If the audit opinion increases, the better the audit delay will decrease.

4. The coefficient of firm size $(\mathrm{X} 3)=$ 1.776, meaning that if the firm size increases by 1 unit, it will affect the decrease in audit delay by 1.776 . The coefficients value is negative, indicating a negative relationship between firm size (X3) and audit delay (Y). It means that if the company's size increases, the audit delay will decrease.

5. Profitability coefficient $(\mathrm{X} 4)=-0.503$, meaning that if profitability increases by 1 unit, it will affect the decrease in audit delay by $0.503(50.3 \%)$. The coefficients value is negative, indicating a negative relationship between profitability (X4) and audit delay (Y). It means that if profitability increases, audit delay will decrease.

\section{F Statistic Test (Simultaneous)}

Table 5. Simultaneous Test Results

\begin{tabular}{|c|c|c|c|}
\hline & \multicolumn{2}{|c|}{ Weighted Statistics } & \\
\hline R-squared & 0.115964 & $\begin{array}{l}\text { Mean dependent } \\
\text { var }\end{array}$ & 36.21606 \\
\hline $\begin{array}{l}\text { Adjusted } \\
\text { R-squared }\end{array}$ & 0.106920 & S.D. dependent var & 18.67639 \\
\hline $\begin{array}{l}\text { S.E. } \\
\text { regression }\end{array}$ & 17.64973 & Sum squared resid & 121801.6 \\
\hline F-statistic & 12.82240 & Durbin-Watson stat & 1.239778 \\
\hline $\begin{array}{l}\text { Prob } \\
\text { (F-statistic) }\end{array}$ & 0.000000 & & \\
\hline
\end{tabular}

The F test is used to simultaneously see the effect of audit tenure, audit opinion, firm size, and profitability on audit delay. This effect needs to be tested to see whether this regression model can be continued by performing a t-test (partial) or not. Suppose the results of the $\mathrm{F}$ test conclude that all independent variables have a significant effect on the dependent variable. In that case, this regression model can be continued by performing a t-test. On the other hand, if it has no effect, then the t-test (partial test) does not need to be carried out because all independent variables do not affect the dependent variable.

The simultaneous test results conducted in this study indicate that the value of Prob. F-Statistic is 0.000 , which is smaller than 0.05 . The results of this $F$ test indicate that all independent variables together (simultaneously) have a significant effect on the dependent variable, namely audit delay. T-test (partial test) was conducted to see what independent variables affect audit delay,

\section{Test Statistics t (Partial)}

The t-statistical test shows how far the influence of one independent variable individually in explaining the dependent variable is. The hypothesis is formulated as follows:

1. $\mathrm{H} 0: \mathrm{Xi}=0$, meaning that the independent variable has no significant effect on the dependent variable.

2. H1: Xi 0, meaning that the independent variable significantly influences the dependent variable.

Acceptance or rejection of the hypothesis in a study can be done with the following criteria:

1. If the statistical significance value is > 0.05 , then $\mathrm{HO}$ is accepted. It means that an independent variable individually does not influence the dependent variable.

2. If the significance value of $t$ statistic $<0.05$, then $\mathrm{H} 0$ is rejected. It means that an independent variable individually affects the dependent variable.

Table 6. t-Test Results (Partial)

\begin{tabular}{|l|l|l|l|l|}
\hline Variable & Coefficient & Std. Error & t-Statistic & Prob. \\
\hline C & 117.2596 & 13.65748 & 8.585741 & 0.0000 \\
\hline X1 & 0.358517 & 0.404387 & 0.886568 & 0.3759 \\
\hline X2 & -11.20593 & 2.383918 & -4.700635 & 0.0000 \\
\hline X3 & -1.776340 & 0.899809 & -1.974130 & 0.0491 \\
\hline X4 & -0.503214 & 0.109860 & -4.580503 & 0.0000 \\
\hline
\end{tabular}


Based on Table 6. above, the results of the t-test state that audit opinion, firm size, and profitability partially have a significant effect on audit delay. Meanwhile, the audit tenure variable does not significantly affect audit delay.

\section{Coefficient of Determination Test}

The coefficient of determination (R2) essentially measures how far the model can explain the variation of the dependent variable. If the value of $\mathrm{R} 2$ is small, it means that the ability of the independent variables to explain the variation of the dependent variable is minimal. Vice versa.

Table 7. Coefficient of Determination Results

\begin{tabular}{|l|l|l|c|}
\hline & Weighted Statistics & $\begin{array}{l}\text { Mean dependent } \\
\text { var }\end{array}$ & 36.21606 \\
\hline R-squared & 0.115964 & S.D. dependent var & 18.67639 \\
\hline $\begin{array}{l}\text { Adjusted } \\
\text { squared }\end{array}$ & 0.106920 & Sum squared resid & 121801.6 \\
\hline S.E. of regression & 17.64973 & $\begin{array}{l}\text { Durbin-Watson } \\
\text { stat }\end{array}$ & 1.239778 \\
\hline F-statistic & 12.82240 & \multicolumn{2}{|c|}{} \\
\hline Prob(F-statistic) & 0.000000 & Source: Results of data processing with Eviews9 \\
\hline
\end{tabular}

Based on Table 7. above, the value of R Square (R2) in this research model is 0.116 , which means that the independent variables, namely audit tenure, audit opinion, firm size, and profitability, can explain or describe audit delay in manufacturing companies listed on the Indonesia Stock Exchange. Of 0.116 or $11.6 \%$. While the remaining $88.4 \%$ is influenced or explained by other variables not included in this research model.

\section{Moderating Test}

The relationship between the independent variable and the dependent variable, there is a possibility that can be influenced by other variables not included in the statistical model, which are called moderating variables or moderating variables. The moderating variable used in this study is the reputation of the Public Accounting Office. In seeing whether the reputation of the Public Accounting Firm can be used as a moderating variable in this research model, it can be seen based on its interaction with the research model in the following table.

Table 8. Regression Results With Moderating Variables

\begin{tabular}{|l|l|l|l|l|}
\hline Variable & Coefficient & Std. Error & t-Statistic & Prob. \\
\hline $\mathrm{C}$ & 109.0702 & 17.62482 & 6.188442 & 0.0000 \\
\hline $\mathrm{X} 1$ & 1.893485 & 0.718823 & 2.634146 & 0.0088 \\
\hline $\mathrm{X} 2$ & -13.64967 & 3.139034 & -4.348367 & 0.0000 \\
\hline $\mathrm{X} 3$ & -1.218788 & 1.182218 & -1.030934 & 0.3032 \\
\hline $\mathrm{X} 4$ & -0.786290 & 0.198689 & -3.957398 & 0.0001 \\
\hline $\mathrm{Z}$ & 0.488752 & 25.03021 & 0.019526 & 0.9844 \\
\hline $\mathrm{X} 1 * \mathrm{Z}$ & -2.200455 & 0.877066 & -2.508883 & 0.0125 \\
\hline $\mathrm{X} 2 * \mathrm{Z}$ & 7.066595 & 4.577102 & 1.543902 & 0.1234 \\
\hline $\mathrm{X} 3 * \mathrm{Z}$ & -0.299459 & 1.639367 & -0.182668 & 0.8552 \\
\hline $\mathrm{X} 4 * \mathrm{Z}$ & 0.430288 & 0.233061 & 1.846245 & 0.0656 \\
\hline \multicolumn{7}{|c|}{ Source: Results of data processing with Eviews 9} \\
\hline
\end{tabular}

Based on the table above, it can be seen the interaction between the moderating variable, namely the reputation of the Public Accountant Office, with each independent variable, namely audit tenure, audit opinion, firm size, and profitability on audit delay. These results explain that the interaction between the moderating variable and audit tenure significantly affects audit delay because the significance value is less than 0.05 .

\section{CONCLUSION}

Based on the results of data analysis and research discussion, the following conclusions can be drawn:

1. Audit tenure does not significantly affect audit delay in manufacturing companies listed on the Indonesia Stock Exchange.

2. Audit opinion has a negative and significant effect on audit delay in manufacturing companies listed on the Indonesia Stock Exchange.

3. Firm size has a negative and significant effect on audit delay in manufacturing companies listed on the Indonesia Stock Exchange.

4. Profitability has a negative and significant effect on audit delay in manufacturing companies listed on the Indonesia Stock Exchange.

5. The reputation of the Public Accountant Office can strengthen the effect of audit tenure on audit delay in manufacturing companies listed on the Indonesia Stock Exchange. 
6. The reputation of the Public Accountant Office cannot moderate the effect of audit opinion on audit delay in manufacturing companies listed on the Indonesia Stock Exchange.

7. The reputation of the Public Accountant Office cannot moderate the effect of firm size on audit delay in manufacturing companies listed on the Indonesia Stock Exchange.

8. The reputation of the Public Accountant Office cannot moderate the effect of profitability on audit delay in manufacturing companies listed on the Indonesia Stock Exchange.

\section{LIMITATIONS OF THE RESEARCH}

This study has limitations that can be taken into consideration for future researchers in order to get better results, namely as follows:

1. This research was only conducted on manufacturing companies listed on the Indonesia Stock Exchange in 20092020.

2. This study only uses measurements and formulas that the researcher knows only so that the research results may differ compared to different measurements and formulas.

\section{SUGGESTION}

Based on the conclusions in this study, some suggestions can be made as follows:

1. In the study results, it can be seen that audit opinion, firm size, and profitability are proven to have a negative and significant effect on audit delay in manufacturing companies listed on the Indonesia Stock Exchange. It is recommended that companies listed as manufacturing companies on the Indonesia Stock Exchange continue to pay attention to the level of audit opinion obtained every year pay attention to its size (total company assets). The company's profitability because the better the level of the audit opinion, the size of the company, and the profitability it has will be able to reduce the audit delay of the company so that the resulting audit delay will be shorter.

2. The results in this study indicate that the reputation of the Public Accountant Office can strengthen the effect of audit tenure on audit delay in manufacturing companies on the Indonesia Stock Exchange. At the same time, the partial effect of audit tenure on audit delay is not significant. It shows that the company should consider the reputation of the Public Accountant Office to minimize the audit delay of the company. Companies are advised to prefer to use the Public Accountant Office already affiliated with The Big Four because of its reputation. Of course, the quality of the audit produced is much better than other tiny Public Accounting Offices, so using the services of a reputable Public Accountant Office will help the company to shorten audit delays.

3. Future research is expected to reexamine the effect of other variables that can affect audit delay in companies other than those used by researchers in this study. Several variables that can be studied include audit switching, solvency, audit quality, and financial distress.

\section{Acknowledgement: None}

\section{Conflict of Interest: None}

\section{Source of Funding: None}

\section{REFERENCES}

1. Akingunola, R. O., Soyemi, K. A., dan Okunuga, R. (2018). Client Attributes and the Audit Report Lag in Nigeria. Market Forces Journal of Management, Business, and Economics, 8 (1), 30-41.

2. Amani, F. A. (2016). Pengaruh Ukuran Perusahaan, Profitabilitas, Opini Audit, Dan Umur Perusahaan Terhadap Audit Delay (Studi Empiris pada Perusahaan Property dan Real Estate yang Terdaftar di Bursa Efek 
Indonesia pada Tahun 2012-2014). Jurnal Nominal. 5 (1). 135-150.

3. Apriliane, M. D. (2015). Analisis Faktorfaktor yang Mempengaruhi Audit Delay (Studi Empiris pada Perusahaan Manufaktur yang Terdaftar di Bursa Efek Indonesia Tahun 2008-2013). Yogyakarta: Universitas Negeri Yogyakarta.

4. Apriyana, N. dan Rahmawati, D. (2017). Pengaruh Profitabilitas, Solvabilitas, Ukuran Perusahaan, dan Ukuran Kantor Akuntan Publik Terhadap Audit Delay Pada Perusahaan Properti dan Real Estate Yang Terdaftar di Bursa Efek Indonesia Periode 2013-2015. Jurnal Nominal. 6 (2). 108-124.

5. Ashton, R. H., Willingham, J. J., dan Elliott, R. K. (1987). An Empirical Analysis of Audit Delay. Journal of Accounting Research. 25 (2): 275-292.

6. Astuti, I. R. dan Darsono, D. (2012). Pengaruh Faktor Keuangan dan Non Keuangan Terhadap Penerimaan Opini Audit Going Concern. Diponegoro Journal Of Accounting. 1 (1). 84-93.

7. Azizkhani, M., Daghani, R., dan Shailer, G. (2018). Audit Firm Tenure and Audit Quality in a Constrained Market. The International Journal of Accounting, 53 (3), 167-182.

8. Brigham, E. F., dan Houston, J. F. (2014). Dasar-dasar Manajemen. Keuangan. Jakarta: Salemba Empat.

9. Dao, M., dan Pham, T. (2014). Audit tenure, Auditor Specialization, and Audit Report Lag. Managerial Auditing Journal, 29 (6): 490-512.

10. Dewangga, A. (2015). Faktor-Faktor Yang Berpengaruh Terhadap Audit Report Lag. Diponegoro Journal of Accounting. 4 (3).

11. Dong, B., Robinson, D., dan Xu, L. (2018). Auditor-Client Geographic Proximity And Audit Report Timeliness. Advances in Accounting, 40, 11-19.

12. Estrini, D. H. dan Laksito, H. (2013). Analisis Faktor-Faktor Yang Mempengaruhi Audit Delay (Studi Empiris Pada Perusahaan Manufaktur Yang Terdaftar di BEI Tahun 2009-2011). Diponegoro Journal of Accounting. 2 (2). 1-10.

13. Febrianty. (2011). Faktor-Faktor Yang Berpengaruh Terhadap Audit Delay Perusahaan Sektor Perdagangan Yang Terdaftar di BEI Periode 2007-2009. Jurnal Ekonomi dan Informasi Akuntansi (JENIUS). 1 (3): 294-320.
14. Giri, F. E. (2010). Pengaruh Tenur Kantor Akuntan Publik (Kantor Akuntan Publik) dan Reputasi Kantor Akuntan Publik Terhadap Kualitas Audit: Kasus Rotasi Wajib Auditor di Indonesia. Seminar Nasional Akuntansi XIII, Purwokerto.

15. Habib, A., Bhuiyan, M. B. U., Huang, J. J., dan Miah, M. S. (2018). Determinants of Audit Report Lag: A Meta-Analysis. International Journal of Auditing. 23 (1).

16. Habib, A., dan Bhuiyan, M. B. U. (2011). Audit Firm Industry Specialization And The Audit Report Lag. Journal of International Accounting, Auditing, and Taxation, 20 (1), 32-44.

17. Indriyani, R. E. dan Supriyati. (2012). Faktorfaktor yang Mempengaruhi Audit Report Lag Perusahaan Manufaktur di Indonesia dan Malaysia. The Indonesian Accounting Review. 2 (2): 185-202.

18. Kartika, A. (2009). Faktor-Faktor Yang Mempengaruhi Audit Delay di Indonesia (Studi Empiris Pada Perusahaan-Perusahaan LQ 45 Yang Terdaftar Di Bursa Efek Jakarta). Jurnal Bisnis dan Ekonomi (JBE), 16 (1): 1-17.

19. Khalatbari, A., Ramezanpour, I., dan Haghdoost, J. (2013). Studying the Relationship of Earnings Quality and Audit Delay in Accepted Companies in Tehran Securities. International Research Journal of Applied and Basic Sciences. 6 (5): 549-555.

20. Mariani, K. dan Latrini, M. Y. (2016). Komite Audit sebagai Pemoderasi Pengaruh Reputasi Auditor dan Tenure Audit terhadap Audit Report Lag. E-Jurnal Akuntansi Universitas Udayana. 16 (3): 2122-2148.

21. Michael, C. J., dan Rohman, A. (2017). Pengaruh Audit Tenure dan Ukuran Kantor Akuntan Publik Terhadap Audit Report Lag Dengan Spesialisasi Industri Auditor Sebagai Variabel Moderasi (Studi Empiris Pada Perusahaan Manufaktur Yang Terdaftar di Bursa Efek Indonesia Tahun 2013-2015). Diponegoro Journal of Accounting 6 (4): 112.

22. Miradhi, M. D., dan Juliarsa, G. (2016). Ukuran Perusahaan Sebagai Pemoderasi Pengaruh Profitabilitas dan Opini Auditor Pada Audit Delay. E-Jurnal Akuntansi Universitas Udayana, 16 (1). 388-415.

23. Muhammad, M I. (2020). Effects of Auditor Attributes on Audit Reporting Lag: Empirical Evidence From Nigerian Service 
Firms. Asian Journal of Empirical Research, $10(4), 127-136$.

24. Murti, A. S. (2016). Pengaruh Ukuran Perusahaan dan Profitabilitas Pada Audit Delay Dengan Reputasi Kantor Akuntan Publik Sebagai Variabel Pemoderasi. EJurnal Akuntansi Universitas Udayana, 16 (1). 275-305.

25. Naimi, M., Shafie, R., dan Wan-Hussin, W. N. (2010). Corporate Governance and Audit Report Lag in Malaysia. Asian Academy of Management Journal of Accounting and Finance. Vol 6. No. 2. 57-84.

26. Obradovic, A., Mizdrakovic, V., \& Avlijas, G. (2018). Analysis of Audit Report Lag on Serbian Stock Exchange. Paper Presented at The Singidunum University International Scientific Conference. Singidunum University, Belgrade.

27. Pourali, M. R., Jozi, M., Rostami, K. H., Taherpour, G. R., dan Niazi, F. (2013). Investigation of Effective Factors in Audit Delay: Evidence from Tehran Stock Exchange (TSE). Research Journal of Applied Sciences, Engineering and Technology. 5 (2):

28. 405-410.Puspitasari, E. dan Sari, A. N. (2012). Pengaruh Karakteristik Perusahaan Terhadap Lamanya Wktu Penyelesaian Audit (Audit Delay) Pada Perusahaan Manufaktur Yang terdaftar di Bursa Efek Indonesia. Jurnal Akuntansi \& Auditing. 9 (1).

29. Puspitasari, K. D. dan Lartini, M. Y. (2014). Pengaruh Ukuran Perusahaan, Anak Perusahaan, Leverage, dan Ukuran Kantor Akuntan Publik Terhadap Audit Delay. E-
Jurnal Akuntansi Universitas Udayana. 8 (2).

30. Singh, A., Singh, H., Sultana, N., dan Evans, J. (2019). Independent and Joint Effects of Audit Partner Tenure and Non-Audit Fees on Audit Quality. Journal of Contemporary Accounting \& Economics, 15 (2), 186-205.

31. Soedarsa, H. G. dan Nurdiawansyah. (2017). Pengaruh Faktor Internal dan Eksternal Pada Audit Delay (Studi Empiris Pada Perusahaan Makanan dan Minuman Yang Terdaftar di Bursa Efek Indonesia. Jurnal Akntansi \& Keuangan. 8 (2). 67-89.

32. Sugiyono. (2011). Metode Penelitian Kuantitatif dan Kualitatif dan R\&D. Bandung: CV Alfabeta.

33. Wulandari, I. N. P., dan Wiratmaja, I. D. N. (2017). Pengaruh Audit Tenure dan Ukuran Perusahan Klien Terhadap Audit Delay Dengan Financial Distress Sebagai Pemoderasi. E-Jurnal Akuntansi Universitas Udayana, 21 (1): 701-729.

34. Yuliusman., Putra, W. E., Gowon, M., Dahmiri., dan Isnaeni, N. (2020). Determinant Factors Audit Delay: Evidence from Indonesia. International Journal of Recent Technology and Engineering (IJRTE). 8 (6). 1088. 1095.

How to cite this article: Gabriel Abdillah, Iskandar Muda, Erwin Abubakar. Factors affecting audit delay with reputation of public accountant office as a moderating variable in manufacturing companies listed on the IDX in 2009-2020. International Journal of Research and Review. 2022; 9(2): 381-392. DOI: https:// doi.org/10.52403/ijrr.20220249 